University of Michigan Law School

University of Michigan Law School Scholarship Repository

\title{
Income Inequality, Progressive Taxation and Tax Expenditures
}

James R. Hines Jr.

University of Michigan Law School, jrhines@umich.edu

Available at: https://repository.law.umich.edu/book_chapters/181

Follow this and additional works at: https://repository.law.umich.edu/book_chapters

Part of the Income Distribution Commons, Law and Economics Commons, Social Welfare Commons, and the Tax Law Commons

\section{Publication Information \& Recommended Citation}

Hines, James R., Jr. "Income Inequality, Progressive Taxation and Tax Expenditures." In The Political Economy of Inequality: U.S. and Global Dimensions, edited by Sisay Asefa and Wei-Chiao Huang, 145-66. Kalamazoo, Mich.: Upjohn Press, 2020.

This Book Chapter is brought to you for free and open access by the Faculty Scholarship at University of Michigan Law School Scholarship Repository. It has been accepted for inclusion in Book Chapters by an authorized administrator of University of Michigan Law School Scholarship Repository. For more information, please contact mlaw.repository@umich.edu. 


\title{
The Political Economy of Inequality
}

\section{U.S. and Global Dimensions}

\author{
Sisay Asefa \\ Wei-Chiao Huang \\ Editors
}

2020

W.E. Upjohn Institute for Employment Research Kalamazoo, Michigan 


\title{
Library of Congress Cataloging-in-Publication Data
}

Names: Sisay Asefa, 1950-, editor. | Huang, Wei-Chiao, editor.

Title: The political economy of inequality : U.S. and global dimensions /

Sisay Asefa, Wei-Chiao Huang, editors.

Description: Kalamazoo : W.E. Upjohn Institute for Employment Research, 2020. | Includes bibliographical references and index. | Summary: "This book encapsulates the six papers delivered during the 54th Werner Sichel Lecture Series, held on the campus of Western Michigan University during the academic year 2017-2018. The book's title is taken from the theme for that year's lecture series, 'The Political Economy of Inequality: U.S. and Global Dimensions."” — Provided by publisher. Identifiers: LCCN 2020006532 (print) | LCCN 2020006533 (ebook) | ISBN 9780880996716 (paperback) | ISBN 9780880996723 (cloth) | ISBN 9780880996730 (ebook)

Subjects: LCSH: Income distribution. | Income distribution-United States. |

Economic policy. | Retirement-Government policy.

Classification: LCC HB523 .P65 2020 (print) | LCC HB523 (ebook) | DDC $339.2-$ dc23

LC record available at https://lccn.loc.gov/2020006532

LC ebook record available at https://lccn.loc.gov/20200065633

\author{
(C) 2020
}

W.E. Upjohn Institute for Employment Research

$300 \mathrm{~S}$. Westnedge Avenue

Kalamazoo, Michigan 49007-4686

The facts presented in this study and the observations and viewpoints expressed are the sole responsibility of the authors. They do not necessarily represent positions of the W.E. Upjohn Institute for Employment Research.

Cover design by Allshouse Graphic Design.

Index prepared by Diane Worden.

Printed in the United States of America.

Printed on recycled paper. 


\title{
7 \\ Income Inequality, Progressive Taxation, and Tax Expenditures
}

\author{
James R. Hines Jr. \\ University of Michigan and NBER
}

There are important and growing concerns about income inequality in the United States and other high-income countries. These concerns reflect rising apprehension about the political and social consequences of inequality and worries that the advance of technology, expanding international trade and investment, and other economic developments may have significantly widened income gaps in recent decades and will continue to do so in the future. In the United States, these concerns have prompted renewed calls for political activism and vigorous searches for policy measures that might improve the relative economic positions of low- and middle-income Americans.

There are many ways in which government policies can and do influence the distribution of income, though redistributive policies can be costly from the standpoint of economic efficiency and growth. Since as a realistic matter it is unlikely that feasible reforms to any one individual government program would fully address current income distribution concerns, it is useful to consider a range of policy options and their likely effects on the distribution of income and the performance of the economy. It is particularly valuable to identify measures that address distributional concerns efficiently.

This chapter considers the design of a tax system in an economy with significant income inequality, focusing on the impact of provisions - such as tax deductions and tax credits - that offer benefits to some but not all taxpayers. Taxation directly affects the distribution of after-tax incomes by imposing larger burdens on some than it does on others, and it indirectly affects the distribution of income through the government programs it finances. A tax program designed to address income distribution concerns is one that imposes burdens based on abil- 
ity to pay and that guarantees adequate funding for appropriate government programs; consequently, tax reforms can be evaluated based on the extent to which they permit the tax system to perform these functions.

The U.S. federal income tax imposes tax burdens based largely on ability to pay. The U.S. tax system is progressive, meaning that a taxpayer's burden measured as a percentage of income generally rises with income. The U.S. tax system achieves this progressivity largely with tax rates that increase with income and with the provision of refundable tax credits to low-income working families. As a result, most of the revenue raised by the U.S. federal income tax comes from high-income taxpayers, with a sizable portion of the income-earning U.S. population paying zero or negative federal income taxes.

Despite the progressivity of the U.S. income tax, there are frequently voiced concerns that the system affords too many unwarranted tax breaks, particularly for high-income taxpayers. ${ }^{1}$ These concerns are understandable but misplaced. They are understandable because much of the popular discussion of tax policy focuses on apparent inequities created by the availability of tax preferences for which certain taxpayers and not others are eligible. For example, only those taxpayers who itemize their tax deductions are able to receive tax reductions due to mortgage payments, charitable contributions, and state and local tax payments. Prior to passage of the 2017 Tax Cuts and Jobs Act, only about 30 percent of the taxpaying population chose to itemize deductions, with the remaining 70 percent claiming the standard deduction instead. ${ }^{2}$ Since the 30 percent who itemized their deductions were concentrated among high-income taxpayers, it follows that this highincome group received most of the benefits of the favorable federal tax treatment of mortgage interest, charitable contributions, and state and local tax payments. By increasing the standard deduction, the Tax Cuts and Jobs Act significantly reduced the number of U.S. taxpayers claiming the standard deduction, and in the process it further concentrated the benefits of tax deductions among the wealthy. Hence, a simple calculation of the distribution of the benefits of itemized deductions might conclude that the provision of these deductions reduces tax equity by providing benefits almost entirely to taxpayers with high incomes.

On closer examination, it becomes apparent that equity-based concerns about these tax preferences are misplaced, because in fact tax preferences are critical features of progressive tax systems - and indeed, 
are what make it possible for tax systems to exhibit high degrees of progressivity, with all the social benefits that are associated with progressivity. There are two reasons for this, the first of which is that tax preferences make it possible to design taxes efficiently, since by providing preferential taxation of highly responsive activities it is possible to differentiate taxes in a way that is less costly to the economy. The economic distortions associated with high tax rates are important considerations in limiting the extent of taxation and tax progressivity, both in theory and in practice. Since high marginal tax rates discourage income production, the cost of imposing high tax rates rises with the degree to which economic activity is sensitive to taxation. Governments can choose to offer tax preferences for activities that are highly sensitive to taxation, which subjects these activities to lower effective tax rates, and thereby subjects relatively insensitive activities to comparatively higher rates of taxation. This type of tax design reduces the efficiency cost of high tax rates and thereby makes it feasible to implement a more progressive tax system.

The second reason tax preferences facilitate tax progressivity is that properly designed tax preferences adjust tax burdens according to ability to pay, which increases the attractiveness of imposing a highly progressive tax-rate structure. One of the important equity concerns about high degrees of tax progressivity is that high tax rates may be unduly burdensome to taxpayers in certain circumstances. For example, even a very-high-income taxpayer may find it impossible or infeasible also to pay federal income taxes at high rates if simultaneously confronted with a combination of extraordinary medical bills, high state taxes, high alimony payments, and other claims on resources. The adoption of sympathetic tax treatment in the form of deductions for medical and other expenses makes legislators and the general public more willing than they would otherwise be to impose high tax rates on those with very high incomes.

As a result, an equitable tax system has a relatively narrow tax base and high tax rates, with rates that increase sharply with income. By applying high tax rates to affluent taxpayers, the system can raise revenue that more than compensates for revenue lost from tax deductions and tax credits, and that has desirable distributional properties in the bargain. Such a system offers favorable rates, refundable credits, and other tax benefits for low-income families. The tax system thereby imposes 
tax burdens according to ability to pay and raises revenue sufficient to fund needed government programs. By imposing burdens according to ability to pay and in offering a sound system of government finance, a tax system with high rates and appropriate deductions and tax credits automatically addresses the income-distribution concerns that appropriately motivate much of the current tax-policy discussion.

There is an alternative to such a system: it is a much more strippeddown income tax that offers very few if any deductions and tax credits. There is considerable popular appeal to such a broad-based, low-rate tax system, due in part to its simplicity and in part to the low rates. The archetypal broad-based, low-rate tax system is known as a Haig-Simons income tax, after the fundamental contributions of Robert Murray Haig (1921) and Henry Calvert Simons (1938). In the Haig-Simons income tax, all income is subject to taxation, without provision of deductions or tax credits corresponding to individual taxpayer situations. The virtue of such simplicity is not to be lightly dismissed, but this form of simplicity comes at the cost of considerable loss of tax equity, because such a tax fails to accommodate individual circumstances, and it is unrealistic to think that a Haig-Simons income tax would ever be imposed at highly progressive rates. Indeed, even the appeal to low tax rates immediately reveals that there is a limit to the range of possible tax progressivity, which limits the extent to which those who are best positioned to pay taxes ultimately do so. Those who advocate for broad-based, low-rate tax systems frequently fail to recognize the intimate connection between the breadth of the tax base and the extent to which the government is able to adopt a system that taxes according to ability to pay. The purpose of this chapter is to draw attention to this connection, and to recommend that the United States and other countries do more to tailor their tax systems in ways that make them more progressive.

\section{DISTRIBUTIONAL PROPERTIES OF THE U.S. INCOME TAX}

The U.S. federal government collects revenue from several sources, of which two are by far the most important: 1) employment-related payroll taxes, which finance Social Security and Medicare, and 2) the per- 
sonal income tax, which finances most of the rest of the government. ${ }^{3}$ This paper focuses on the income tax, which is the primary discretionary source of revenue for the federal government - and which by its nature is the part of the revenue system that is most amenable to the imposition of burdens according to ability to pay. U.S. payroll taxes are unlike income and other taxes in that eligibility for retirement benefits, disability insurance, and medical insurance requires payment of employment taxes - whereas receipt of other federal benefits are not conditional on paying income taxes. For example, workers who have higher wage and salary income, and therefore pay greater Social Security taxes, receive higher monthly benefits from the Social Security system when they retire. Furthermore, the Social Security system provides benefits in a highly progressive way, with income replacement rates that are much higher at low incomes than they are at higher incomes. Consequently, the Social Security system achieves its distributional objectives not through its tax features but instead through its benefit formula - which would make any distributional examination of Social Security taxes incomplete, given the close connection of Social Security taxes and benefits.

U.S. federal income-tax burdens rise with income, largely reflecting the progressive nature of tax rates. The latest available data cover pre-2018 federal law, with Table 7.1 presenting calculations for tax year 2014 . In that year, an adjusted gross income of $\$ 465,600$ put a taxpayer in the top 1 percent of the income distribution, and such taxpayers faced average tax rates of 27.2 percent. This top 1 percent of the U.S. income distribution had 20.6 percent of aggregate U.S. personal income that year and paid 39.5 percent of total federal income taxes. An adjusted gross income of $\$ 189,000$ put a taxpayer in the top 5 percent of the income distribution; and this group faced average tax rates of 23.6 percent, earned 36 percent of aggregate U.S. personal income that year, and paid 60 percent of federal income taxes. By contrast, the half of the United States that had incomes below $\$ 38,200$ faced average tax rates of just 3.5 percent, had only 11.3 percent of personal income, and paid just 3.5 percent of federal income taxes.

Federal personal-income tax burdens in 2014 (and in other years) rise with income levels. This is largely the product of tax rates that increase with income, exempt amounts, and standard and personal deductions that permit taxpayers to earn significant income before it 
Table 7.1 Income Distribution, Tax Rates, and Tax Payments, 2014

\begin{tabular}{lcccc}
\hline $\begin{array}{l}\text { Income } \\
\text { groups }(\%)\end{array}$ & $\begin{array}{c}\text { Income cutoffs } \\
(\$ 000 \mathrm{~s})\end{array}$ & $\begin{array}{c}\text { Average tax } \\
\text { rates }(\%)\end{array}$ & $\begin{array}{c}\text { Cumulative } \\
\text { incomes }(\%)\end{array}$ & $\begin{array}{c}\text { Cumulative tax } \\
\text { payments }(\%)\end{array}$ \\
\hline Top 1 & 465.6 & 27.2 & 20.6 & 39.5 \\
Top 5 & 189.0 & 23.6 & 36.0 & 60.0 \\
Top 10 & 133.4 & 21.3 & 47.2 & 70.9 \\
Top 25 & 77.7 & 17.8 & 68.9 & 86.8 \\
Top 50 & 38.2 & 15.5 & 88.7 & 97.3 \\
Bottom 50 & & 3.5 & 11.3 & 3.5 \\
\hline
\end{tabular}

NOTE: The table presents average federal income tax rates, total incomes, and total federal income tax payments by six income groups for tax year 2014. Income groups are classified by adjusted gross income (AGI) as reported on tax forms. Income cutoffs denote the minimum AGI to be included in the group. Cumulative incomes denote the fraction of total U.S. AGI earned by members of the income group; similarly, cumulative tax payments denote the fraction of total U.S. federal income tax payments by members of the group.

SOURCE: Dungan (2017).

becomes taxable, as well as refundable tax credits available to lowincome earners. In 2014, a married couple was not taxable until its income exceeded amounts covered by exemptions and deductions, and then was initially taxable at just 10 percent for the first $\$ 18,150$ of net taxable income. Such a couple then faced a 15 percent tax rate until its taxable income reached $\$ 73,800$, after which point the marginal tax rate became 25 percent. The marginal income-tax rate rose to 28 percent at an income of $\$ 148,851,33$ percent at an income of $\$ 226,851,35$ percent at an income of $\$ 405,101$, and 39.6 percent on any portion of income exceeding \$457,601. Furthermore, the Earned Income Tax Credit and the Child Tax Credit were available primarily for low-income families.

Despite the evident progressivity of the federal income tax, it is possible for tax reform to make the system much more progressive than it was in 2014 or is today. One aspect of federal taxation that is commonly argued to work against tax progressivity is the provision of exclusions, deductions, and tax credits, all of which are commonly called "tax expenditures" (Surrey 1973). The most important single "tax expenditure" is the tax exclusion for employer-provided health insurance. Other significant tax expenditures include the preferential treatment of retirement accounts; deductions for state and local taxes, mortgage interest, and charitable contributions; the favorable tax treatment of capital 
gains; and various tax credits. Table 7.2 displays the largest federal tax expenditures for Fiscal Year 2016, with accompanying magnitudes of forgone federal tax revenue because of these tax expenditures. Many of these tax expenditures benefit high-income taxpayers.

Table 7.3 presents the distribution of federal personal income tax expenditures by income group for Tax Year 2013. The first column offers evidence on tax exclusions, which consist of the benefits of the favorable tax treatment of employer-provided health insurance, pension contributions, and income; the favorable tax treatment of capital gains on assets held until death; and other smaller exclusions. As the table indicates, 7 percent of the aggregate value of these tax exclusions is enjoyed by taxpayers whose incomes are in the top 1 percent of the U.S. income distribution. While the aggregate value of these benefits for the top 1 percent is obviously disproportionate to the number of taxpayers, it is actually rather small compared to the roughly 39.5 percent of tax

Table 7.2 Largest Individual Tax Expenditures, 2016

\begin{tabular}{lc}
\hline Tax expenditure & $\begin{array}{c}2016 \text { amount } \\
\text { (\$ billions) }\end{array}$ \\
\hline Exclusions from taxable income: & 164.6 \\
Employer contributions for health care and insurance & 156.1 \\
Employer pension contributions and earnings & 38.4 \\
Social Security and railroad retirement benefits & 32.9 \\
Capital gains at death & 32.9 \\
Interest on state and local government bonds & 31.3 \\
Fringe benefits provided under cafeteria plans & 29.2 \\
Capital gains on sales of principal residences & \\
Tax deductions: & 96.6 \\
State and local income, sales, and property taxes & 59.0 \\
Mortgage interest on owner-occupied residences & 55.2 \\
Charitable contributions & 130.9 \\
Reduced tax rates on dividends and long-term capital gains & \\
Tax credits: & 73.0 \\
Earned Income Tax Credit & 55.0 \\
Child Tax Credit &
\end{tabular}

NOTE: The table presents the aggregate dollar values (in billions) of the largest individual tax expenditure items for Fiscal Year 2016.

SOURCE: Joint Committee on Taxation (2017a). 
Table 7.3 Share of Tax Expenditures by Income Group, 2013

\begin{tabular}{lccccc}
\hline Income & $\begin{array}{c}\text { Tax } \\
\text { exclusions } \\
\text { group }(\%)\end{array}$ & $\begin{array}{c}\text { Tax } \\
\text { deductions } \\
(\%)\end{array}$ & $\begin{array}{c}\text { Capital gains } \\
\text { preferences } \\
(\%)\end{array}$ & $\begin{array}{c}\text { Tax } \\
\text { credits } \\
(\%)\end{array}$ & $\begin{array}{c}\text { Total tax } \\
\text { expenditures } \\
(\%)\end{array}$ \\
\hline Top 1 & 7 & 30 & 68 & 0 & 17 \\
Top 20 & 45 & 81 & 93 & 3 & 51 \\
60-80 & 23 & 13 & 5 & 12 & 18 \\
$40-60$ & 16 & 4 & 2 & 19 & 13 \\
20-40 & 10 & 1 & 0 & 29 & 10 \\
Bottom 20 & 5 & 0 & 0 & 37 & 8 \\
\hline
\end{tabular}

NOTE: Figures in the table report the fraction of total U.S. tax benefits of each tax preference category received by each of the designated income groups, as defined by adjusted gross income. "Tax exclusions" consist of tax benefits from the exclusion from taxable income of employer-provided health insurance, net pension contributions and earnings, capital gains on assets transferred at death, a portion of Social Security and railroad retirement benefits, and other items. "Tax deductions" consist of tax benefits from the itemized deductions for state and local taxes, mortgage interest, charitable contributions, and others. "Capital gains preferences" are the benefits of the preferential tax rates at which long-term gains are taxed. "Tax credits" consist of tax benefits from the Earned Income Tax Credit, the Child Tax Credit, and other available credits. "Total tax expenditures" is the sum of all of these tax benefits.

SOURCE: CBO (2013).

payments (and 20.6 percent of income) accounted for by the top 1 percent of taxpayers. Table 7.3 indicates that the top 20 percent of income earners in 2013 received 45 percent of the tax benefits from tax exclusions - which, again, while disproportionate to that group's numbers, is rather less than the share of this top-income quintile in tax payments or income. By contrast, taxpayers whose incomes are in the bottom two income quintiles received 15 percent of the aggregate tax benefit of exclusions, which is a sizable benefit considering that the bottom half of income earners has 11.3 percent of aggregate income and pays just 3.5 percent of aggregate U.S. income taxes.

The second column of Table 7.3 presents information on the distribution of the benefits of tax deductions, which include benefits from deducting state and local taxes, mortgage interest payments, charitable contributions, and other expenses. These benefits are more heavily concentrated among high-income taxpayers than are the benefits of tax exclusions. As the table indicates, taxpayers whose incomes are in the 
top 1 percent receive 30 percent of the aggregate benefits of tax deductions; income earners in the top quintile of the distribution receive 81 percent of the aggregate benefits of tax deductions. These percentages correspond roughly to shares of aggregate tax payments. By contrast, income earners in the bottom quintile of the distribution receive only negligible benefits from tax deductions, reflecting both the low tax rates against which they take deductions and the very small fraction of such taxpayers who itemize deductions rather than taking the standard deduction.

The third and fourth columns of Table 7.3 display information on distributions of the benefits of capital-gain preferences and tax credits. These two series exhibit very different distributional properties. The benefits of capital-gain preferences - the low rates at which long-term capital gains are taxed - are very strongly concentrated among highincome taxpayers, with the top quintile of income earners enjoying 93 percent of the aggregate benefit of these low tax rates, while the bottom two quintiles of income earners enjoy only negligible benefits. The opposite is true of the benefits of tax credits, which arise almost entirely from the Earned Income Tax Credit and the Child Tax Credit. The bottom two quintiles of income earners enjoy 66 percent of the aggregate benefits of tax credits, whereas the top quintile of income earners receive only negligible benefits.

The fifth column of Table 7.3 displays shares of aggregate benefits from all tax expenditures taken together. Because of the significance of tax deductions and capital-gain preferences, aggregate tax expenditure benefits are again concentrated among high-income taxpayers, with 17 percent accruing to the top 1 percent of taxpayers, and 51 percent to the top quintile. By contrast, the bottom quintile of income earners receives only 8 percent of the aggregate benefits of tax expenditures, and the 20-40 percent quintile receives 10 percent of the aggregate benefits.

Table 7.4 presents information on the benefits of aggregate tax expenditures expressed as shares of after-tax incomes. This method of presenting the values of tax expenditures implicitly modifies the entries to adjust for the dollar values of the benefits provided by different types of tax expenditures. For example, since the aggregate dollar value of tax exclusions greatly exceeds the aggregate dollar value of tax deductions, the distribution of tax exclusions has greater impact on the final distribution of after-tax incomes than does the distribution of tax deductions. 
Table 7.4 Values of Tax Expenditures as Shares of After-Tax Income, by Income Group, 2013 (\%)

\begin{tabular}{lccccc}
\hline $\begin{array}{l}\text { Income } \\
\text { group }(\%)\end{array}$ & $\begin{array}{c}\text { Tax } \\
\text { exclusions } \\
(\%)\end{array}$ & $\begin{array}{c}\text { Tax } \\
\text { deductions } \\
(\%)\end{array}$ & $\begin{array}{c}\text { Capital gains } \\
\text { preferences } \\
(\%)\end{array}$ & $\begin{array}{c}\text { Tax } \\
\text { credits } \\
(\%)\end{array}$ & $\begin{array}{c}\text { Total tax } \\
\text { expenditures } \\
(\%)\end{array}$ \\
\hline Top 1 & 3.2 & 3.9 & 5.3 & 0.0 & 13.1 \\
Top 20 & 4.7 & 2.5 & 1.7 & 0.1 & 9.4 \\
60-80 & 5.2 & 0.8 & 0.2 & 0.7 & 7.3 \\
40-60 & 5.0 & 0.4 & 0.1 & 1.5 & 7.3 \\
20-40 & 4.5 & 0.2 & 0.0 & 3.3 & 7.9 \\
Bottom 20 & 4.2 & 0.0 & 0.0 & 8.1 & 11.7 \\
\hline
\end{tabular}

NOTE: Figures in the table report values of total U.S. tax benefits of each tax preference category received by each of the designated income groups, expressed as fractions of group income. "Tax exclusions" consist of tax benefits from the exclusion from taxable income of employer-provided health insurance, net pension contributions and earnings, capital gains on assets transferred at death, a portion of Social Security and railroad retirement benefits, and other items. "Tax deductions" consist of tax benefits from the itemized deductions for state and local taxes, mortgage interest, charitable contributions, and others. "Capital gains preferences" are the benefits of the preferential tax rates at which long-term gains are taxed. "Tax credits" consist of tax benefits from the Earned Income Tax Credit, the Child Tax Credit, and other available credits. "Total tax expenditures" is the sum of all of these tax benefits.

SOURCE: CBO (2013).

Despite a normalization by after-tax incomes, it remains the case that the values of tax deductions and capital-gain preferences appear to be concentrated among high-income taxpayers: the top 1 percent receive benefits from tax deductions equal to 3.9 percent of their incomes, and they receive benefits from capital-gains preferences equal to 5.3 percent of their incomes. By contrast, taxpayers with incomes in the bottom 40 percent of the income distribution receive benefits from tax deductions equal to just 0.2 percent of their incomes and receive only negligible benefits from capital gains preferences. The benefits of tax exclusions in Table 7.4 appear to be spread across the population roughly in proportion to after-tax incomes, and the benefits of tax credits are very strongly concentrated among low-income taxpayers, with those in the bottom quintile of the income distribution receiving tax credits worth 8.1 percent of their incomes. By contrast, taxpayers in the top quintile of the income distribution receive benefits from tax credits equal to just 0.1 percent of their incomes. 
The fifth column of Table 7.4 presents the distribution of the dollar values of tax expenditures measured as percentages of after-tax incomes. This distribution of benefits is largely flat across the middle three quintiles of the income distribution, with somewhat greater density in the bottom and top quintiles, and a mild concentration of benefits for the top 1 percent of income earners.

The evidence indicates that taxpayers in the top 20 percent of the U.S. income distribution receive a majority of the benefits of tax expenditures, from which many people quite understandably draw the conclusion that tax exclusions, deductions, and credits are antiprogressive. One problem with this inference is that existing tax expenditures offer benefits roughly in proportion to after-tax incomes, suggesting that they serve largely as factors that reduce effective tax rates by somewhat constant amounts. The second problem is that evaluating tax expenditures in isolation relies on a view of the world in which everything elsenotably including tax rates-stays unchanged while tax preferences disappear. This is unrealistic; governments choose tax rates together with tax preferences, and if tax preferences were reduced in magnitude, then government would also change tax rates. Consequently, in order to know just what effect tax expenditures have on the distribution of income, it is necessary to understand the principles that governments apply in designing their tax systems.

\section{THE 2017 TAX CUTS AND JOBS ACT}

In December 2017, the United States enacted a major tax reform, commonly known by the bill's original title, the Tax Cuts and Jobs Act (TCJA). This legislation was initially directed at reforming the U.S. system of corporate and international taxation, and while the TCJA did reduce the U.S. corporate tax rate from 35 percent to 21 percent and introduce major changes to the U.S. system of taxing foreign income, the final bill also included significant cuts to individual taxes and the taxation of income earned by unincorporated businesses. As a result, forecasts predicted that the TCJA would reduce federal revenue collections by $\$ 1.456$ trillion over 10 years; and even in the scenario in which the tax reduction has the effect of stimulating the economy, federal rev- 
enues over that time period would decline by $\$ 1.071$ trillion because of the bill's provisions (Joint Committee on Taxation 2017b).

The 2017 legislation significantly reduced individual taxes by lowering tax rates, almost doubling the standard deduction, doubling the Child Tax Credit, increasing the exempt amount under the individual alternative minimum tax (AMT), and making several other changes. There were also several provisions that increased individual taxes, notably by removing personal exemptions, reducing and eliminating several popular itemized deductions, and changing the method by which bracket amounts are indexed to inflation. The combination of rate reductions and limits on itemized deductions produced a lower-rate, broader-based personal income tax system. It also produced a personal income tax system with burdens less well targeted to ability to pay.

The 2017 TCJA reduced average effective tax rates at every income level. Table 7.5 presents a distributional analysis of the effect of the TCJA, comparing tax burdens by income level in 2017 (prior to application of the TCJA's provisions) and 2019. As the table indicates, the TCJA reduced personal income taxes by $\$ 259.5$ billion in 2019 , lowering the average personal income tax rate from 20.7 percent to 19.0 percent. The tax reductions were concentrated among higher-income taxpayers, in part reflecting the reality that these individuals pay the majority of federal income taxes. The roughly 1.7 million taxpayers with incomes of $\$ 500,000$ and above saw their aggregate federal taxes decline by $\$ 60.8$ billion between 2017 and 2019, whereas the 37.5 million taxpayers with incomes in the $\$ 20,000-\$ 40,000$ range received an aggregate tax reduction of just $\$ 8.4$ billion.

The second and third columns of Table 7.5 present average tax rates in 2017 and 2019 for each of the listed income groups. Average tax rates declined for each of these groups by between 0.5 and 3.1 percent, with most of the large reductions materializing for high-income taxpayers. For example, the average tax rate of taxpayers with $\$ 1$ million or more of income fell from 32.5 percent in 2017 to 30.2 percent in 2019; and the average tax rate of taxpayers with annual incomes in the $\$ 500,000$ to $\$ 1$ million range declined from 30.9 percent in 2017 to 27.8 percent in 2019. By contrast, the average tax rate of taxpayers with annual incomes in the $\$ 20,000-\$ 30,000$ range fell by only 0.5 percent, from 3.9 percent to 3.4 percent. As a result, the 2017 TCJA delivered its larg- 
Table 7.5 2019 Distributional Effects of the 2017 Tax Cuts and Jobs Act

\begin{tabular}{|c|c|c|c|c|}
\hline \multirow{2}{*}{$\begin{array}{l}\text { Income category } \\
\qquad(\$ 000)\end{array}$} & \multirow{2}{*}{$\begin{array}{l}\text { Tax reduction } \\
\text { ( } \$ \text { billions })\end{array}$} & \multicolumn{2}{|c|}{ Average tax rates $(\%)$} & \multirow{2}{*}{$\begin{array}{l}\text { Number of } \\
\text { taxpayers (in } \\
\text { millions) }\end{array}$} \\
\hline & & 2017 & 2019 & \\
\hline Less than 10 & 0.4 & 9.1 & 8.6 & 19.3 \\
\hline $10-20$ & 1.8 & -0.7 & -1.2 & 20.6 \\
\hline $20-30$ & 3.0 & 3.9 & 3.4 & 21.5 \\
\hline $30-40$ & 5.4 & 7.9 & 7.0 & 16.0 \\
\hline $40-50$ & 6.7 & 10.9 & 9.9 & 12.8 \\
\hline $50-75$ & 23.0 & 14.8 & 13.5 & 27.4 \\
\hline $75-100$ & 22.4 & 17.0 & 15.6 & 17.8 \\
\hline $100-200$ & 70.4 & 20.9 & 19.4 & 30.7 \\
\hline $200-500$ & 65.5 & 26.4 & 23.9 & 9.2 \\
\hline $500-1,000$ & 23.9 & 30.9 & 27.8 & 1.1 \\
\hline 1,000 and over & 36.9 & 32.5 & 30.2 & 0.6 \\
\hline Total & 259.5 & 20.7 & 19.0 & 177.0 \\
\hline
\end{tabular}

NOTE: The table presents the aggregate tax reductions between 2017 and 2019, and the average federal income tax rates in 2017 and 2019, for 11 income groups classified by adjusted gross income as reported on tax forms.

SOURCE: Joint Committee on Taxation (2019).

est tax reductions (as measured relative to pretax incomes) to the most affluent taxpayers.

Table 7.6 explores the sources of tax burden changes for affected taxpayer income groups. Entries in the table represent the aggregate magnitudes of tax reductions between 2017 and 2019 for which the listed tax bill provisions were responsible. Thus, for example, the tax rate reductions in the 2017 bill lowered by $\$ 57.8$ billion the aggregate 2019 tax liabilities of taxpayers in the $\$ 200,000-\$ 500,000$ income group. The same taxpayer group also received $\$ 23.8$ billion in aggregate tax savings from the 2017 bill's significant reduction in the alternative minimum tax but paid an additional $\$ 25.8$ billion in aggregate taxes because of the removal of personal exemptions.

Some patterns are evident from the information in Table 7.6. The tax rate reductions in the 2017 bill reduced aggregate 2019 tax collections by $\$ 198.4$ billion, with the benefits concentrated among highincome taxpayers. The 2017 bill reduced aggregate tax collections under the alternative minimum tax by $\$ 38.6$ billion; almost all of this 
Table 7.6 2019 Distributional Effects of Specific Provisions of the 2017 Tax Cuts and Jobs Act

\begin{tabular}{|c|c|c|c|c|c|c|}
\hline $\begin{array}{l}\text { Income } \\
\text { category } \\
(\$ 000)\end{array}$ & $\begin{array}{c}\text { Rate } \\
\text { reduction } \\
\text { (\$ billions) }\end{array}$ & $\begin{array}{c}\text { Alternative } \\
\text { minimum } \\
\operatorname{tax}(\mathrm{AMT}) \\
(\$)\end{array}$ & $\begin{array}{c}\text { Personal } \\
\text { exemptions } \\
(\$)\end{array}$ & $\begin{array}{l}\text { Standard } \\
\text { deduction } \\
(\$)\end{array}$ & $\begin{array}{l}\text { Itemized } \\
\text { deductions } \\
(\$)\end{array}$ & $\begin{array}{c}\text { Child Tax } \\
\text { Credit } \\
(\$)\end{array}$ \\
\hline Less than 10 & 0.0 & $1 \mathrm{~m}$ & $-1 \mathrm{~m}$ & $182 \mathrm{~m}$ & 0 & $82 \mathrm{~m}$ \\
\hline $10-20$ & 0.0 & $4 \mathrm{~m}$ & $-932 \mathrm{~m}$ & $3.3 \mathrm{~b}$ & $-4 \mathrm{~m}$ & $1.0 \mathrm{~b}$ \\
\hline $20-30$ & 0.3 & $0 \mathrm{~m}$ & $-2.8 b$ & $5.9 \mathrm{~b}$ & $-60 \mathrm{~m}$ & $2.4 \mathrm{~b}$ \\
\hline $30-40$ & 1.3 & $2 \mathrm{~m}$ & $-3.8 b$ & $7.0 \mathrm{~b}$ & $-153 \mathrm{~m}$ & $3.5 \mathrm{~b}$ \\
\hline $40-50$ & 2.7 & $6 \mathrm{~m}$ & $-4.9 \mathrm{~b}$ & $7.7 \mathrm{~b}$ & $-231 \mathrm{~m}$ & $4.3 \mathrm{~b}$ \\
\hline $50-75$ & 12.3 & $9 \mathrm{~m}$ & $-16.5 b$ & $20.4 \mathrm{~b}$ & $-1.1 \mathrm{~b}$ & $9.8 \mathrm{~b}$ \\
\hline $75-100$ & 14.7 & $9 \mathrm{~m}$ & $-17.7 b$ & $16.8 \mathrm{~b}$ & $-1.7 b$ & $7.7 \mathrm{~b}$ \\
\hline $100-200$ & 61.1 & $690 \mathrm{~m}$ & $-54.6 \mathrm{~b}$ & $37.2 \mathrm{~b}$ & $-9.1 b$ & $23.9 \mathrm{~b}$ \\
\hline $200-500$ & 57.8 & $23.8 \mathrm{~b}$ & $-25.8 b$ & $9.6 \mathrm{~b}$ & $-21.5 b$ & $13.5 \mathrm{~b}$ \\
\hline $500-1,000$ & 18.6 & $13.2 \mathrm{~b}$ & $-39 \mathrm{~m}$ & $1.1 \mathrm{~b}$ & $-12.3 b$ & $93 \mathrm{~m}$ \\
\hline $\begin{array}{c}1,000 \text { and } \\
\text { over }\end{array}$ & 29.5 & $873 \mathrm{~m}$ & $-1 \mathrm{~m}$ & $425 \mathrm{~m}$ & $-30.0 \mathrm{~b}$ & 0 \\
\hline Total & 198.4 & $38.6 \mathrm{~b}$ & $-127.1 \mathrm{~b}$ & $109.5 \mathrm{~b}$ & $-\$ 76.2 \mathrm{~b}$ & $66.4 \mathrm{~b}$ \\
\hline
\end{tabular}

NOTE: The table presents the aggregate tax reductions between 2017 and 2019 due to various provisions of the 2017 TCJA, distinguished by income groups as classified by adjusted gross income reported on tax forms. The first column reports tax reductions due to lower tax rates introduced by the TCJA. The second column reports tax reductions due to changes in the alternative minimum tax. The third column reports tax reductions (all of which are negative, so therefore correspond to tax increases) that are due to the elimination of personal exemptions. The fourth column reports tax reductions due to increases in the standard deduction. The fifth column reports tax reductions (all of which are negative, so therefore correspond to tax increases) that are due to limitations on itemized deductions. The sixth column reports tax reductions due to increases in the Child Tax Credit.

SOURCE: Joint Committee on Taxation (2019).

tax reduction was enjoyed by taxpayers in the $\$ 200,000$-to- $\$ 1$-million income range. The elimination of personal exemptions increased aggregate tax liabilities by $\$ 127.1$ billion, most of it paid by taxpayers earning between $\$ 100,000$ and $\$ 500,000$, and virtually none of which paid by taxpayers earning $\$ 500,000$ or above (whose personal exemptions had been already largely phased out under pre-2018 law). Increasing the standard deduction reduced total tax collections by $\$ 109.5$ billion, and almost 70 percent of these benefits were received by taxpayers with incomes between $\$ 50,000$ and $\$ 200,000$. Increasing the Child Tax 
Credit reduced total tax collections by $\$ 66.4$ billion, with the benefits concentrated among taxpayers with middle-to-high incomes; those with incomes below $\$ 20,000$ or above $\$ 500,000$ received almost none of the benefits.

The 2017 legislation made several changes to itemized deductions, limiting the ability of taxpayers to claim deductions for state and local tax payments, mortgage interest payments, casualty losses, moving expenses, alimony payments, and various miscellaneous itemized deductions, including expenses incurred in income-earning activities. In total, these restrictions reduced tax collections by $\$ 76.2$ billion, with the burden heavily concentrated among high-income taxpayers. For example, these limits on itemized deductions increased by $\$ 30.0$ billion the aggregate tax liabilities of taxpayers with incomes of $\$ 1$ million or more, despite the relatively small number of such taxpayers; by contrast, taxpayers with incomes below $\$ 100,000$ (who itemize their deductions at relatively low rates) were largely unaffected.

Those who have long advocated for broad-based, low-rate income taxation got a version of what they asked for with the 2017 Tax Cuts and Jobs Act. The 2017 TCJA reduced rates and removed deductions

and exemptions, moving federal income taxation in the direction of a flatter - and some would argue, simpler - tax system. The federal income tax now collects less money than it would have absent the 2017 changes and does so in a manner that corresponds less to assigning burdens according to ability to pay. While the individual income tax features of the 2017 legislation move the federal revenue system in an unfortunate direction according to these criteria, one way in which the 2017 TCJA is useful is that it illustrates what direction not to take in crafting more wholesale reforms to the tax system.

\section{PRINCIPLES OF INCOME TAXATION}

Countries impose taxes in order to raise revenue to finance their governments. The cost of raising revenue is that the accompanying taxes impose burdens on individuals and businesses that pay the taxes, and these taxes also impose costs on the economy as a whole by distorting economic incentives. Income taxation discourages income pro- 
duction, thereby reducing the efficiency of the economy and running counter to most government objectives. The economic costs of the distortions produced by income taxation almost always rise with the amount of revenue collected, ${ }^{4}$ and with the extent of tax progressivity, so a more distortionary tax system puts downward pressure on government spending and on the extent to which a government will be willing to impose progressive taxes.

The cost of economic distortions is a function of the degree to which price distortions discourage and alter economic activity. Properly designed income exclusions, tax deductions, and tax credits make the tax system less distortionary by directing tax burdens at economic activities that are less responsive to taxation. For example, while all income taxes discourage labor supply, the effects are more dramatic in some instances, and for some groups of workers, than they are for others. Age is an obvious dimension along which the labor supply effects of taxation will usually differ. For example, workers over 60 years old are at far greater risk of retiring than are workers in their forties, so high tax rates are much more likely to drive older workers out of the labor force than they are to induce exit by middle-aged workers. Consequently, an efficient tax system would offer preferential treatment of older workers, all other things being equal. And if a tax system does not offer special exemptions, deductions, or tax credits to elderly workers, then the labor supply responsiveness of this group will put downward pressure on income tax rates in general, since the government will know that higher tax rates significantly reduce the labor supply of a significant portion of the population.

Similar considerations apply to the tax treatment of working families with young children. Since children require care and supervision, parents who work full time must incur out-of-pocket child-care costs, many of which are avoidable if at least one of the parents were to stay home with the children. High tax rates on working parents discourage labor force participation by reducing the net return from working - which has particularly strong effects on income production by parents of young children. The tax system can address this problem most directly by providing tax deductions or tax credits for child-care expenses incurred to accommodate the careers of working parents, which has the effect of more nearly taxing the net economic return to working. While the U.S. tax system currently offers modest versions of 
these deductions and credits, they are very much incomplete, which is why high tax rates on labor income would strongly discourage parental labor-force participation.

Certain forms of capital income are similarly sensitive to taxation. Capital gains offer an important example. Capital gains are taxed on realization rather than accrual, so high rates of capital income taxation strongly discourage owners of appreciated assets from selling their holdings, a phenomenon known as the "lock-in effect." Owners of homes, shares of stock, small businesses, and other valuable properties commonly retain their holdings far longer than they would otherwise want to, in order to delay triggering capital gains taxes. By delaying realizations, an owner implicitly earns returns on the taxes that are not paid in the meantime. To the extent that capital income taxes apply to capital gains, these taxes distort the economy by keeping homeowners in homes they no longer want, investors in shares of companies they no longer want to hold, and business owners in businesses they would prefer to sell to others. Furthermore, anticipation of these taxes discourages investments in the first place. The reality that capital-gains tax realizations are highly sensitive to taxation accounts for the favorable tax treatment that the federal income tax currently affords to income from long-term capital gains. In the absence of such favorable treatment, there would be very strong downward pressure on income tax rates, as governments recognize that the lock-in effect makes high rates very costly.

The examples of the effects of high tax rates on labor supply by elderly workers, labor supply by working parents, and capital gains realizations, are just that: examples. In fact, there are scores of dimensions along which economic activity is more and less responsive to taxation, and which therefore from an efficiency standpoint justify favorable tax treatment of certain taxpayers and activities, and less favorable treatment of others. In the absence of such tax differentiation, the system becomes less efficient and more costly, which makes governments less willing to impose the high tax rates necessary to fund significant government operations and to do so in a progressive manner.

The efficiency considerations that argue in favor of an extensive system of tax preferences in the form of exclusions, deductions, and credits simply add to traditional equity considerations. Taxpayers in different situations, and with different forms of income, have differing 
abilities to pay taxes, and therefore should be subject to taxation at different rates. Children again offer an obvious example. A married couple with labor income of $\$ 80,000$ is clearly in a different economic position from a family consisting of a married couple and five children with a family income of $\$ 80,000$, and it is obvious that the childless couple has in a very practical sense greater real income and therefore greater ability to pay taxes. The U.S. tax system offers only very modest benefits to families with children and would need to do much more in order to adjust properly for the effect of family size on taxpaying ability. Failure to adjust taxes properly for family size means not only that tax burdens are inequitably distributed between taxpaying families, but also that there is downward pressure on tax rates in general, since high tax rates without proper adjustments for family size would impose severe burdens on families in certain circumstances.

Casualty losses offer another example. A family whose home burns down or whose car is stolen incurs significant economic losses in addition to life disruption, insofar as any losses are uninsured. There is a very real sense in which the family's economic income in the year of the incident is lower by the amount of the uninsured loss; and an uninsured loss certainly diminishes a family's ability to pay federal income taxes without incurring significant economic hardship. Until 2018, it was possible for U.S. taxpayers to claim deductions for casualty losses to the extent that such losses exceeded 10 percent of adjusted gross income, but provisions of the 2017 TCJA all but eliminated this deduction. The result is not only the serious inequity that follows from subjecting people to taxation based on inaccurate measures of their annual incomes, but also downward pressure on tax rates, to prevent federal income taxes from imposing significant hardship on families incurring casualty losses and other major economic disruptions.

There are many other dimensions along which the economic situations of taxpaying families differ, and which bear on their ability to pay federal taxes. Families incur medical and educational expenses, job disruptions, investment reversals, loan demands from friends and relatives, and many other circumstances that could be reasonably accommodated by provisions in the tax system. It is a reality that tax breaks given to one group of taxpayers must be made up by higher burdens on other taxpayers, but fortunately there is a simple legislative method of performing such an adjustment, which is to increase tax rates. 


\section{INCOME DISTRIBUTION AND INCOME TAXATION}

A properly designed income tax offers many exclusions, deductions, and credits that accommodate individual situations and thereby adjust tax burdens according to ability to pay. Such a system also imposes relatively heavier burdens on income sources that are least responsive to taxation. These features give the tax system a narrow base and relatively high rates. The high rates are indeed important attributes: a tax system that imposes burdens in accordance with ability to pay has tax rates that rise sharply with income, making the tax-rate schedule highly progressive.

Under any circumstance, it is in the national interest to adopt an income tax that imposes burdens according to ability to pay, but at a time of heightened concern over the distribution of income there is even greater need to adhere to sound principles in crafting income tax provisions. Sound tax design addresses income distribution concerns in several ways. The first is by accommodating individual circumstances and needs, implicitly adjusting tax burdens for differences in real incomes. The second way in which sound tax design addresses income distribution concerns is by facilitating the imposition of a highly progressive tax-rate schedule, one in which high-income taxpayers shoulder much more of the tax burden than do low-income taxpayers. And the third way is that sound tax design makes it feasible to finance significant government expenditures at a reasonable cost, which makes it possible for the government to adopt spending measures that assist low-income and otherwise vulnerable portions of the population.

The United States already has a progressive personal income tax, and it already permits many exclusions, deductions, and tax credits that narrow the base and, to a degree, adjust tax burdens to individual situations. These features of the income tax are widely criticized, notably by advocates for greater tax progressivity, who feel that higher-income taxpayers receive most of the benefits of exclusions, deductions, and tax credits. Evidence from tax filings confirms that this observation is largely correct: high-income taxpayers do indeed benefit from tax expenditures, with slightly more than half of the benefits going to people in the top quintile of the income distribution, and just 8 percent of the benefits going to people in the bottom quintile. 
It is a mistake to conclude from this observation, as so many have, that the answer to making the tax system more progressive lies in selective reductions in tax expenditures. On the contrary: in order to make the tax system more progressive, it is necessary to expand significantly the number of tax expenditures, particularly those that benefit highincome taxpayers. The tax-rate schedule can be made more progressive only by adjusting the taxation of high-income earners for aspects of their economic activities and personal situations that bear on their ability and willingness to pay taxes. Put simply, with different design, it is possible to impose higher tax rates on those with high incomes-but this design will certainly entail significant tax breaks for some with high incomes. The tax system can thereby do much more to align tax burdens with abilities to pay, and to relieve burdens on those who are struggling economically_ but such a system lies open to critique by well-meaning critics who do not appreciate the connection between the breadth of the tax base and the progressivity of tax rates.

Recent legislative developments are far from encouraging. The 2017 Tax Cuts and Jobs Act gave the tax system a narrower base and lower rates, reducing its progressivity and also reducing total tax collections. In eliminating or restricting tax deductions for casualty losses, alimony payments, moving expenses, state and local income tax payments, mortgage interest payments, and expenses incurred in income-earning activities, the 2017 TCJA significantly reduced the extent to which tax burdens align with ability to pay. The tax-rate reductions enacted by the TCJA simply add to the mismatch between tax burdens and taxpaying ability, and the reduced tax collections make it ever more difficult to maintain government programs directed at those in challenging economic circumstances. The TCJA was the product of a political process driven by many considerations, but underlying some of the changes that it enacted was a mistaken sense that a broad-based, low-rate income tax is better than the alternative. Certainly this is not the case if one desires a tax that imposes burdens according to ability to pay and does so in a progressive manner. But even if one's goal is merely efficiency, not equity or progressivity, a good tax system is highly differentiated, offering multiple exclusions, deductions, and credits.

It is important not to overlook efficiency in designing a tax system, whether or not analysts and advocates are motivated by a desire to distribute tax burdens equitably. A more efficient tax system offers 
greater opportunity to pursue all objectives, including those related to equity; and in particular, a more efficient tax system can support a more progressive tax rate structure at lower cost than does a less efficient tax system. In addition, a more efficient tax system makes it feasible for the government to finance worthwhile expenditures, including those that may have redistributive effects. Properly crafted tax expenditures enhance the efficiency of the tax system by directing tax burdens to where they have the least effect of discouraging income production, thereby making the economy more productive.

Postwar U.S. history includes long stretches of time over which tax rates were high and the tax system offered extensive exclusions, deductions, and tax credits. The recent movement has been in the opposite direction, and to little good effect from the standpoints of aligning tax burdens with ability to pay and financing the U.S. government. Those inclined to criticize tax breaks as giveaways to the rich might do well to reflect on the alternative, which is a stripped-down tax system with relatively flat rates and little if any accommodation for the needs of individual taxpayers. In fact, the tax system needs more of what it once had, with high tax rates but also extensive tax preferences for certain types of income and taxpayers in specified circumstances. Only then will it be possible to address the income distribution concerns, and the government financing concerns, that properly motivate those interested in contemporary U.S. economic policy.

\section{Notes}

1. See, for example, Pechman (1977), Century Foundation Working Group (2002), Reid (2017), and Sarin and Summers (2019).

2. In tax year $2015,44.6$ million U.S. tax returns itemized deductions out of 150.5 million returns filed, representing 29.6 percent of the total. These and other tax-return data are available at https://www.irs.gov/statistics/soi-tax-stats -individual-income-tax-return-form-1040-statistics.

3. The Congressional Budget Office (CBO 2019) reports that, in 2018, total U.S. federal government revenues were $\$ 3,329$ billion, of which $\$ 1,684$ billion (50.6 percent) represented individual income taxes, and $\$ 1,171$ billion (35.2 percent) were payroll taxes.

4. Atkinson and Stern (1974) identify exceptional cases in which higher tax revenues can be associated with reduced economic distortions; see Dahlby (2008) for a review of this literature. 


\section{References}

Atkinson, Anthony, and N. H. Stern. 1974. "Pigou, Taxation, and Public Goods." Review of Economic Studies 41(1): 119-128.

Century Foundation Working Group. 2002. Bad Breaks All Around: The Report of the Century Foundation Working Group on Tax Expenditures. New York: Century Foundation Press.

Congressional Budget Office (CBO). 2013. The Distribution of Major Tax Expenditures in the Individual Income Tax System. Washington, DC: Congressional Budget Office.

. 2019. The Budget and Economic Outlook: 2019 to 2029. Washington, DC: Congressional Budget Office.

Dahlby, Bev. 2008. The Marginal Cost of Public Funds: Theory and Application. Cambridge, MA: MIT Press.

Dungan, Adrian. 2017. "Individual Income Tax Shares." SOI Bulletin 36(4): $12-23$.

Haig, Robert Murray. 1921. "The Concept of Income-Economic and Legal Aspects." In The Federal Income Tax, Robert Murray Haig, ed. New York: Columbia University Press, pp. 1-28.

Joint Committee on Taxation. 2017a. Estimates of Federal Tax Expenditures for Fiscal Years 2016-2020. Washington, DC: Joint Committee on Taxation.

. 2017b. Macroeconomic Analysis of the Conference Agreement for H.R. 1, the "Tax Cuts and Jobs Act." Washington, DC: Joint Committee on Taxation.

- 2019. Distributional Effects of Public Law 115-97. Washington, DC: Joint Committee on Taxation.

Pechman, Joseph A., ed. 1977. Comprehensive Income Taxation. Washington, DC: Brookings Institution.

Reid, T. R. 2017. A Fine Mess: A Global Quest for a Simpler, Fairer, and More Efficient Tax System. New York: Penguin Press.

Sarin, Natasha, and Lawrence H. Summers. 2019. "A Broader Tax Base That Closes Loopholes Would Raise More Money than Plans by Ocasio-Cortez and Warren." Boston Globe, March 28.

Simons, Henry C. 1938. Personal Income Taxation: The Definition of Income as a Problem of Fiscal Policy. Chicago: University of Chicago Press.

Surrey, Stanley S. 1973. Pathways to Tax Reform. Cambridge, MA: Harvard University Press. 